\title{
Dextranase 涯加菌穈剈の臨地試験成績*
}

\author{
北村中 也** 森口早紀** 寺田恵美子** \\ 斉藤 邦男*** 二上捷 之***
}

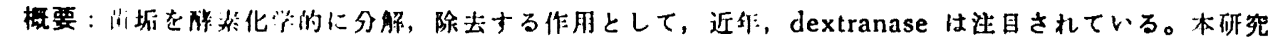

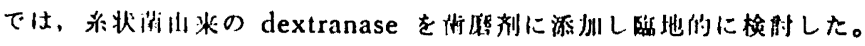

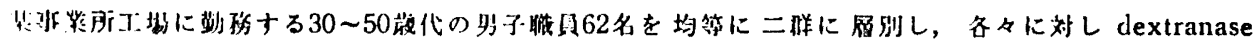

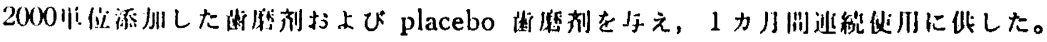

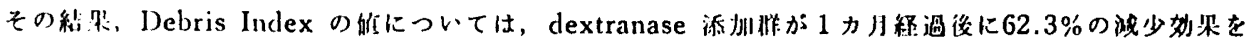

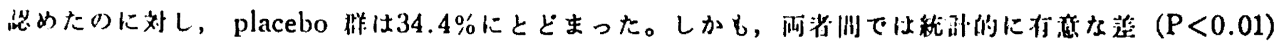
を涊めた。

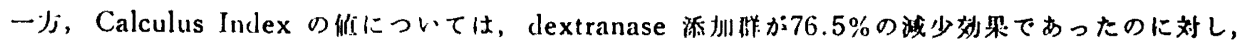

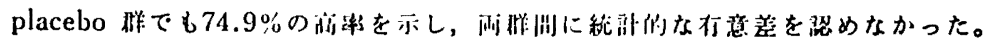

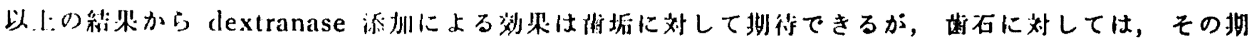
街が低いるのと照わ机た。

\section{緒言}

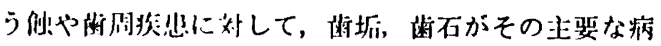
肉となっている芬台が極めて多い1-3)。そのため, これ

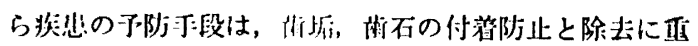
点打执かると帚っても過言ではない。特に,この䂆防

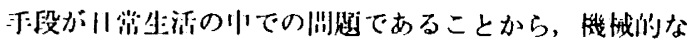

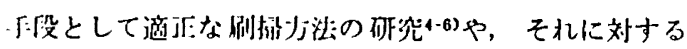

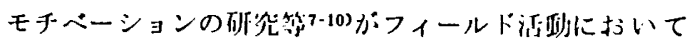
非められている。

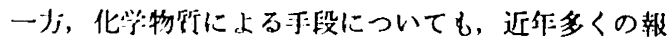

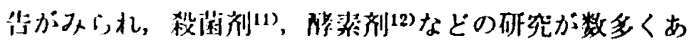
げら机る。なかでも, dextranase の化学们, 生化学的 な作川によるアプローチは, in vitro での多棈合成阻止

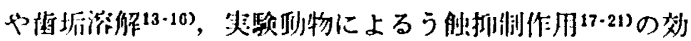

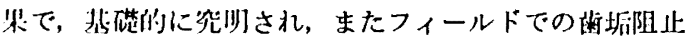

あるいはう仙抑例效果についての究明22,23) もされつつあ る。

このように各見地からの報告がみられるが,著者らは, 三北（抹）より提化された糸状菌由来の dextranase ${ }^{21)}$

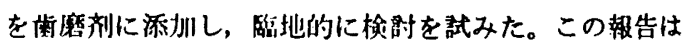

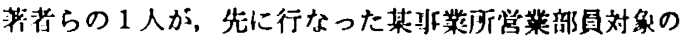

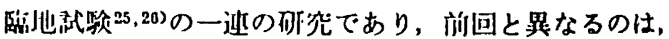

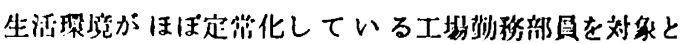

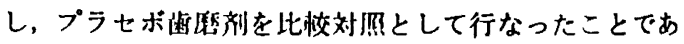
るが，舆咏ある結果を得たので報告する。

\section{研究対象及び研究方法}

\section{1) 砟究対禹}

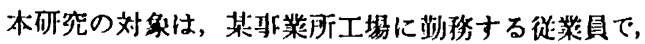
诲科聅想治㷋をを受けていないもののうちから, 然作為に 作秢30〜50歳までの男子-62名を扠州して対象とした。

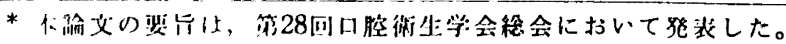

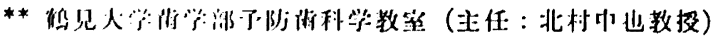

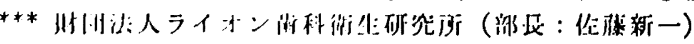

* Deparlment of Preventive Dentistry, Tsurumi University, School of Dental Medicine (Chief: Prof. Tyüya KITAMURA)

** The Lion Foundation for Dental Health (Director: Dr. Shinichi SATO) 㑔和55作 1 Л25日受付 
た，内科疾等による抗生物铂服用者も，本研究対象か ら除外した。なお，榆查は，工場内㟝裙所において行な った。

\section{2) dextranase 原末}

本研究に使用した dextranase は，三击（株）にて生 産された Chaetomium gracile 由来26ののものを使用し た。な㧍，醇素活性はつぎのとおり定莪した。すなわち dextran $1 \%$ 溶液 $1 \mathrm{ml}$ に酻素液 $0.5 \mathrm{ml}$ を加えて $35^{\circ} \mathrm{C}$

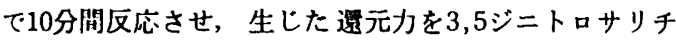
ル酸法により测定し， 1 分間当り $1 \mu \mathrm{g}$ のグルコースに 相当する罯元力を生ずるものを 1 単位とした。

\section{3）被检萪磨剂の組成}

研究に用いた歯磨剂組成は Table 1 に示すとおりで, リン酸カルシウムを主剂としたものを使用した。

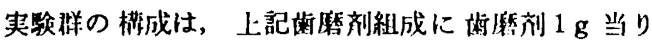

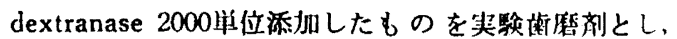
他方 dextranase 然添加のものを対照愎磨剂として，そ れぞれ榄成した。なお， dextranase 添杊による処方の 変慙は純水で調整した。

Table 1 The basic composition of test dentifrice.

\begin{tabular}{l|r}
\hline \multicolumn{1}{c|}{ Components } & \multicolumn{1}{c}{$\%$} \\
\hline Dicalcium phosphate $\left(\mathrm{CaHPO}_{4} \cdot 2 \mathrm{H}_{2} \mathrm{O}\right)$ & 44.0 \\
Binding agents & 1.3 \\
Humectant agents & 20.5 \\
Flavours & 1.0 \\
Foaming agents (ionic surfactant) & 1.2 \\
Foaming agents (nonionic surfactant) & 1.5 \\
Purified water & rest \\
\hline \multicolumn{1}{c}{ Total } & 100.0
\end{tabular}

\section{4）観察项目および期间}

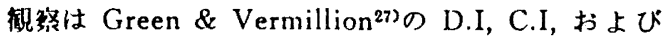
O.H.I.の方法に従った。

微繁回数および斯间は，闻始特，半月経過後および， 1 力月経過後の郡 3 回，同一検查者が行なった。とくに 客钼的な観察が行なえるようこの研究の終了時まで，被

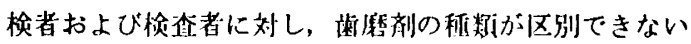
よう配底した。

5) 刷掼方法

刷挷方法については特制な指定を行なわず，現仼各被

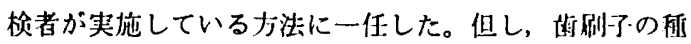
類については, Oral B（ナイロン毛, 省通）に統一し，

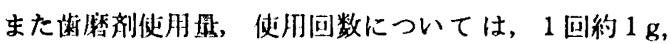
1 口田吼の 2 回と规定した。

6）被梌者の䦌

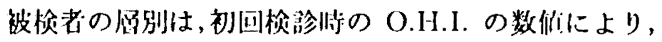

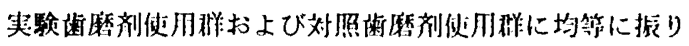
分けた。すなわち，初国 O.H.I. 佔を0.50刻みに 5 段階

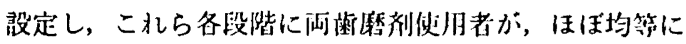
なるように振り分け，雨群洲に統新的な詰かないことを 破琶した。振り分けら扎た内容については Table 2 に示 すと捐であった。なお，D.I. 倠执よび C.I. 倾につい

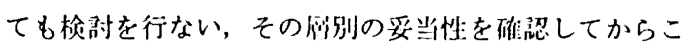
の硎究を進めた。

7）結果の集計と解析

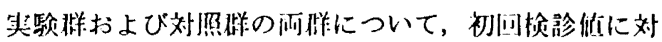

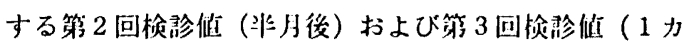
月後）の減少率（歯率で求めた）を次式のと拈り篮義し， 減少度合を很䋈した。

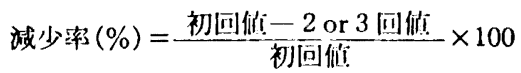

Table 2 Grouping of subjects by levels of O.H.I. in the experimental and control groups.

\begin{tabular}{|c|c|c|c|c|c|c|}
\hline Indices & \multicolumn{2}{|c|}{ D. I. } & \multicolumn{2}{|c|}{ C. I. } & \multicolumn{2}{|c|}{ O.I.I. } \\
\hline $\begin{array}{c}\text { Levels of } \\
\text { O.H.I. }\end{array}$ & $\begin{array}{c}\text { Experimental } \\
\text { group }\end{array}$ & $\begin{array}{c}\text { Control } \\
\text { group }\end{array}$ & $\begin{array}{c}\text { Experimental } \\
\text { group }\end{array}$ & $\begin{array}{l}\text { Control } \\
\text { group }\end{array}$ & $\begin{array}{l}\text { Experimental } \\
\text { group }\end{array}$ & $\begin{array}{l}\text { Control } \\
\text { group }\end{array}$ \\
\hline I. $(0.00 \sim 0.50)$ & $7(7)^{*}$ & $6(6)$ & $5(5)$ & $10(10)$ & $4(4)$ & $7(7)$ \\
\hline II. $(0.51 \sim 1.00)$ & $10(17)$ & $17(23)$ & $16(21)$ & $6(16)$ & $13(17)$ & $11(18)$ \\
\hline III. $(1.01 \sim 1.50)$ & $9(26)$ & $7(30)$ & $3(24)$ & $7(23)$ & $7(24)$ & $10(28)$ \\
\hline IV. $(1.51 \sim 2.00)$ & $4(30)$ & $1(31)$ & $5(29)$ & $6(29)$ & $6(30)$ & $2(30)$ \\
\hline V. $(2.01 \sim 2.50)$ & $1(31)$ & $0(31)$ & $2(31)$ & $2(31)$ & $1(31)$ & $1(31)$ \\
\hline Statistic analysis & \multicolumn{2}{|c|}{ N.S.** } & \multicolumn{2}{|c|}{ N.S. } & \multicolumn{2}{|c|}{ N.S. } \\
\hline
\end{tabular}

* : number of subjects and its cumulative date in the parenthesis.

** : N.S. : not significant. 
Table 3 The daily changes in D.I..

\begin{tabular}{|c|c|c|c|c|c|c|c|}
\hline \multirow{2}{*}{\multicolumn{2}{|c|}{$\begin{array}{c}\text { Test groups } \\
\text { Experimental } \\
\text { Deriods }\end{array}$}} & \multicolumn{3}{|c|}{ Experimental group $(n=31)$} & \multicolumn{3}{|c|}{ Control group $(n=31)$} \\
\hline & & Start & 15 days & 30 days & Start & 15 days & 30 days \\
\hline \multirow{3}{*}{ Maxilla } & Buccal & $0.172^{*}$ & $\begin{array}{l}0.073 \\
(57.6) * *\end{array}$ & $\begin{array}{l}0.092 \\
(46.5)\end{array}$ & 0.107 & $\begin{array}{l}0.102 \\
(4.7)\end{array}$ & $\left(\begin{array}{c}0.113 \\
0\end{array}\right)$ \\
\hline & Lingual & 0.038 & $\begin{array}{l}0.013 \\
(65.8)\end{array}$ & $\begin{array}{l}0.005 \\
(86.8)\end{array}$ & 0.049 & $\begin{array}{c}0.000 \\
(100.0)\end{array}$ & $\begin{array}{c}0.011 \\
(77.6)\end{array}$ \\
\hline & Total & 0.210 & $\begin{array}{l}0.086 \\
(59.0)\end{array}$ & $\begin{array}{l}0.097 \\
(53.8)\end{array}$ & 0.156 & $\begin{array}{c}0.102 \\
(34.6)\end{array}$ & $\begin{array}{c}0.124 \\
(20.5)\end{array}$ \\
\hline \multirow{3}{*}{ Mandibula } & Buccal & 0.134 & $\begin{array}{c}0.000 \\
(100.0)\end{array}$ & $\begin{array}{c}0.032 \\
(76.1)\end{array}$ & 0.065 & $\begin{array}{c}0.024 \\
(63.1)\end{array}$ & $\begin{array}{c}0.054 \\
(16.9)\end{array}$ \\
\hline & Lingual & 0.242 & $\begin{array}{c}0.108 \\
(55.4)\end{array}$ & $\begin{array}{c}0.092 \\
(62.0)\end{array}$ & 0.215 & $\begin{array}{c}0.121 \\
(43.7)\end{array}$ & $\begin{array}{c}0.108 \\
(49.8)\end{array}$ \\
\hline & Total & 0.376 & $\begin{array}{c}0.108 \\
(71.3)\end{array}$ & $\begin{array}{c}0.124 \\
(67.0)\end{array}$ & 0.280 & $\begin{array}{c}0.145 \\
(48.2)\end{array}$ & $\begin{array}{c}0.162 \\
(42.1)\end{array}$ \\
\hline \multicolumn{2}{|c|}{ Total } & 0.586 & $\begin{array}{c}0.194 \\
(66.9)\end{array}$ & $\begin{array}{c}0.221 \\
(62.3)\end{array}$ & 0.436 & $\begin{array}{c}0.247 \\
(43.3)\end{array}$ & $\begin{array}{c}0.286 \\
(34.4)\end{array}$ \\
\hline
\end{tabular}

*: mean D.I. per tooth surface. $\quad{ }^{* *}$ : The reduction rate (\%) from the D.I. at start.

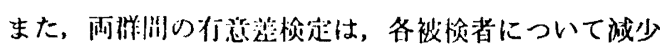

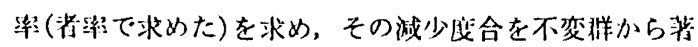

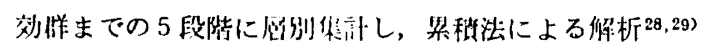
で份拄した。

\section{結 果}

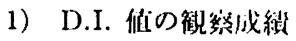

(1) D.I. 值の検診回数による変坵

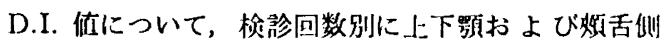
の阶别をした紨果は Table 3 に示寸と拈りである。

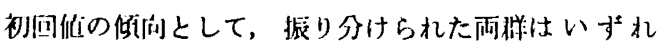

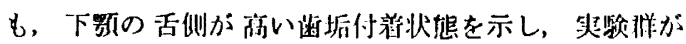

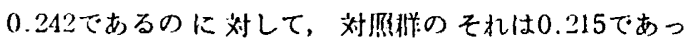

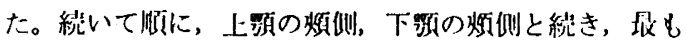

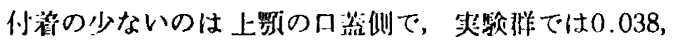
刘照样のそ扎は0.049であった。このことを修純に垶算

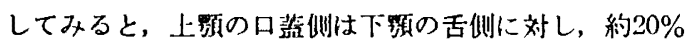
程淁しか断后付辣が琶められない状热であった。

初回 D.I. 倠を樶初の倠として，経日による城少率の 推移をみてみると，両群閌でつぎのように穊繁された。

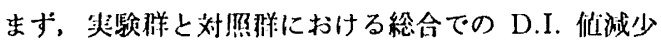

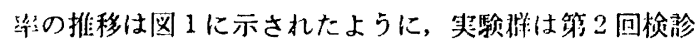
の北月後には $66.9 \%$ 㳦少し，第3 回梌埥の 1 力月後には

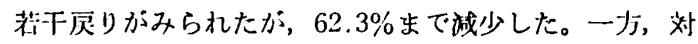
侦群のそれは，兆月後に $43.3 \% ， 1$ 力月後に同様の戻り がみられたが，34.4\%にとどまり，丽群閒の差が認めら

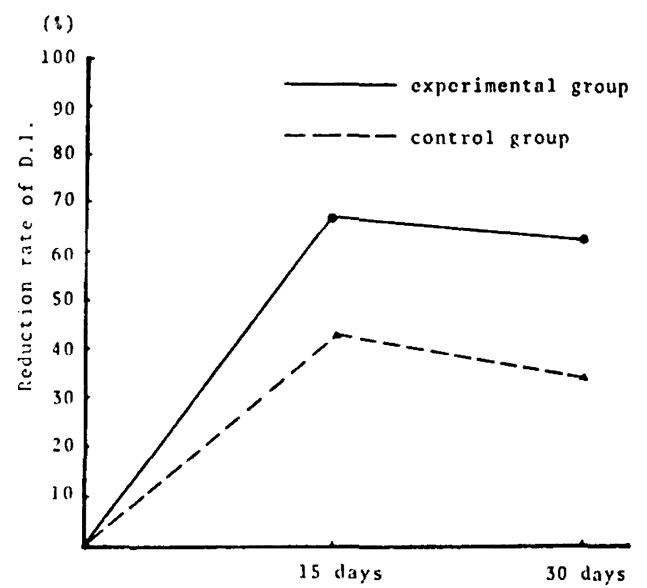

Fig. 1 Daily changes in reduction rates of D.I. (full mouth).

れた。

つぎにこれらの内容を锥䋈与るため上頻 D.I. 值と， 下謌 D.I. 偭にわけて示したのが Fig. 2 および Fig. 3

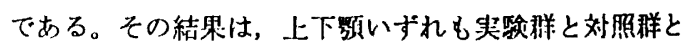
の閣に米月後で荎がみられ，以後はほぼ槛ばいで，前述 の総合での D.I. 值 (Fig. 1) と類似の㑯向がみられた。 但し，西样とも下影 D.I. 倠の方が上影 D.I. 值より10

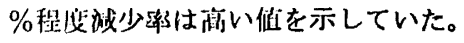

さらにその内容を镍察するため，㛲・舌に分けて示し たのが Fig. 4，5，6およびFig.7である。まず上䫓にお いては, Fig. 4 の煩侧における D.I. の数值が示すとお 
り，刘照群の効果がほとんど照められていない。このこ とは，笑駼群と対照群の差がこの部位で大きく除去効果 があらわれていると思われる。しかし，Fig.5 の口筑侧 に扰ける D.I. 值は，逆のような傾向がみられたが、1カ 月後の值では，ほぼ同程度であり，しかも奏駼群の方は 上㫒するようにみられた。次に下頻においては，Fig.6

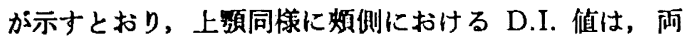
群間の差が大きく認められたのに刘し，Fig.7の舌划で は効果の差は少なかった。

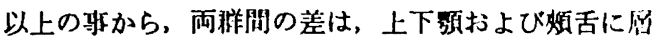
別してみた場合，とくに煩侧において dextranase 添加 による效果が発撮されていた。

(2) D.I. 值化上る統部的裉察

両群問の羑を統訃的に有意差㭘定をするために，次の

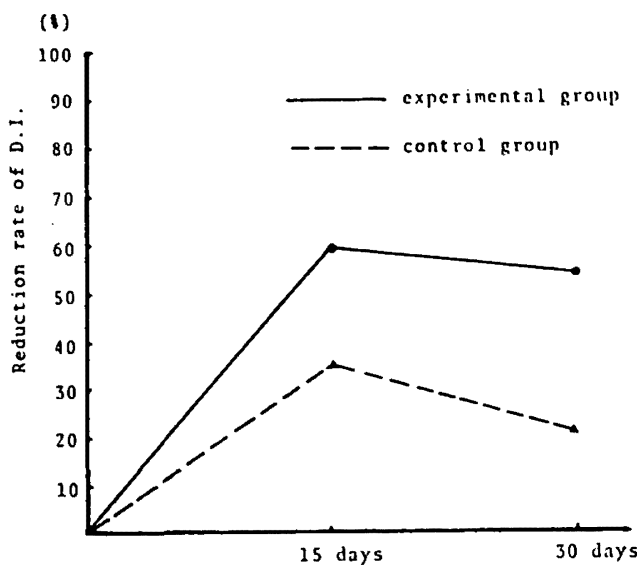

Fig. 2 Daily changes in reduction rates of D.I. on the maxilla.

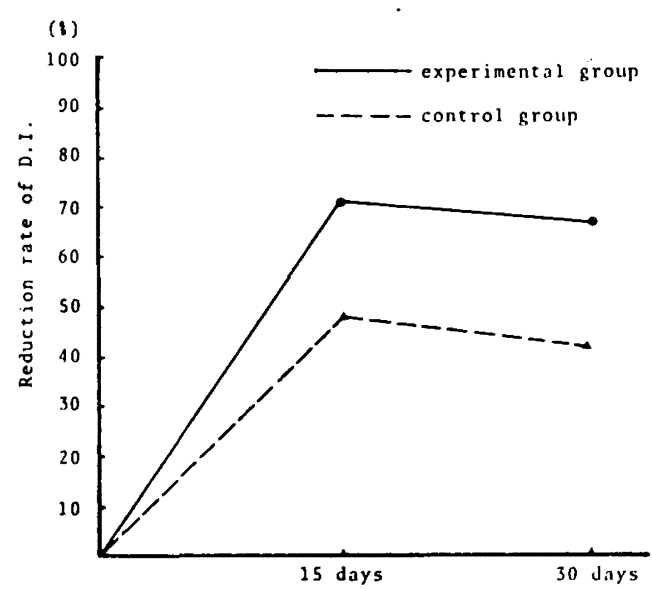

Fig. 3 Daily changes in reduction rates of D.I. on the mandibula.

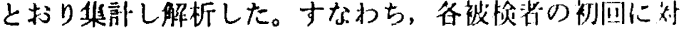

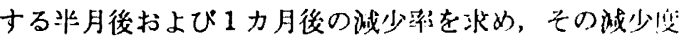
合を「不変」から「著效例」までの 5 段倩に分類した。

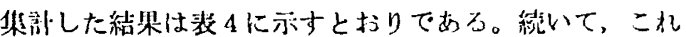
らの結果を 2 元配捆然程法にて処理した分数分析裴は

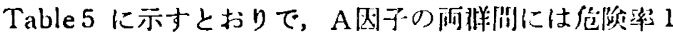
\%で有意の差が椧出された。しかしながら，B因子の期 間については有意差が楒められダ, 従って非月以降は， その效果が惯ばいであることが碓諰された。

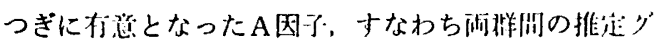
ラフを示したのが Fig. 8 である。半月後での闻渞润の比 校をみると、实险样の「烡刘例」は $45.2 \%$ 占めている

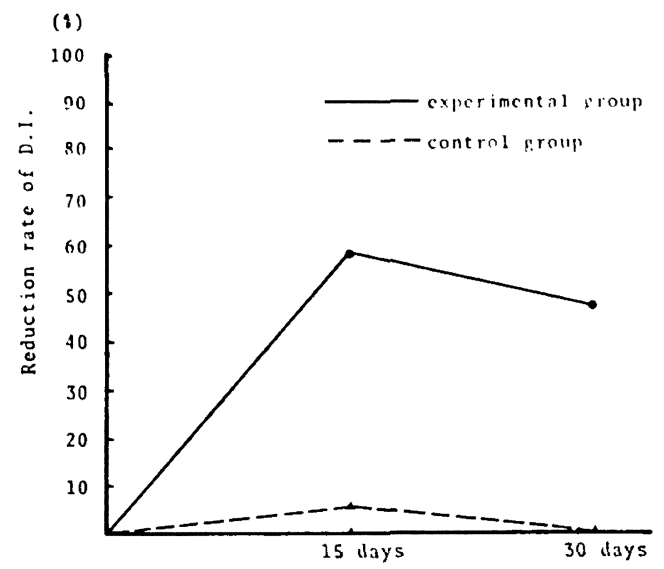

Fig. 4 Daily changes in reduction rates of D.I. on the maxilla and buccal tooth surface.

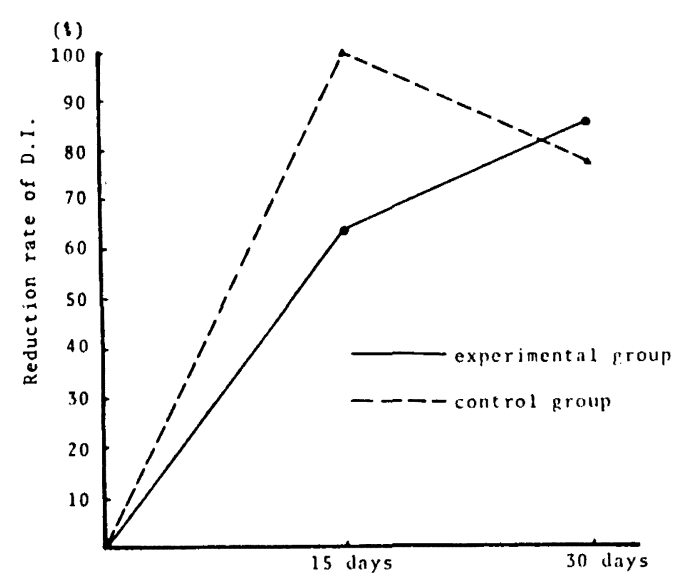

Fig. 5 Daily changes in reduction rates of D.I. on the maxilla and lingual tooth surface. 


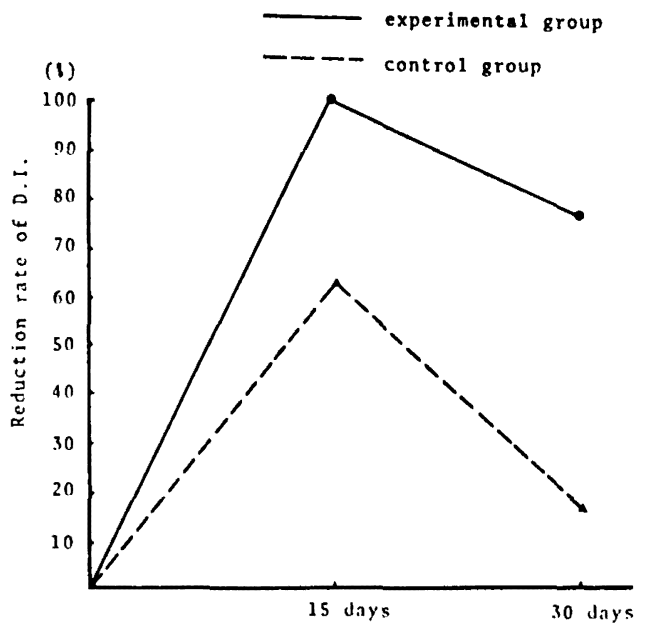

Fig. 6 Daily changes in reduction rates of D.I. on the madibula and buccal tooth surface.

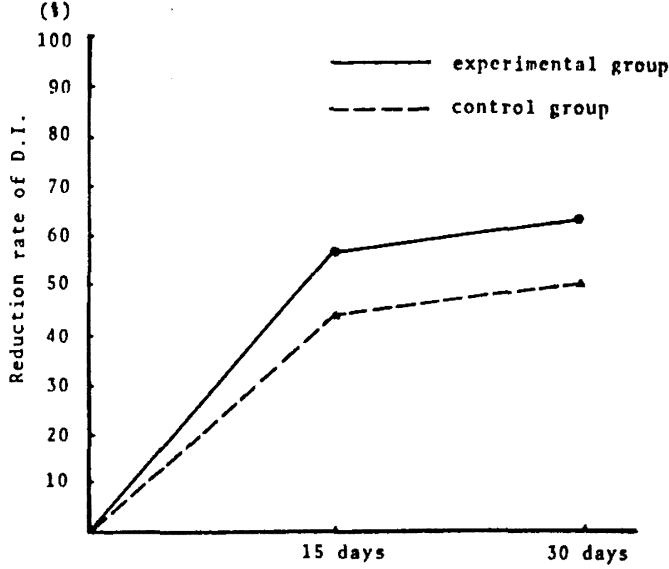

Fig. 7 Daily changes in reduction rates of D.I. on the mandibula and lingual tooth surface.

Table 4 The effect of test dentifrices on the reduction rate of D.I.

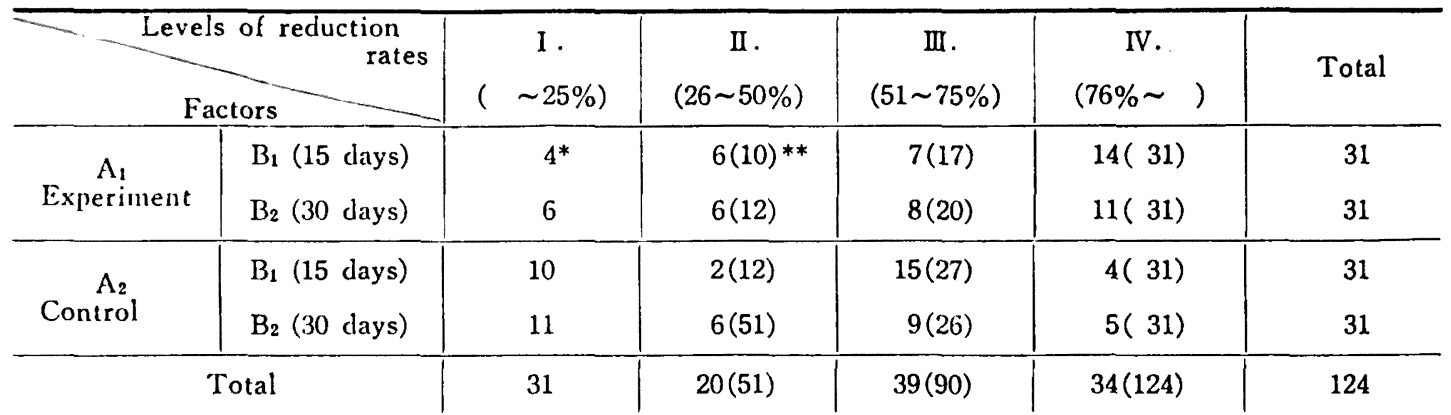

$A$ : Test groups, i. e., Experimental $\left(A_{1}\right)$ and Control $\left(A_{2}\right)$ groups.

$B$ : Experimental periods, i. e., $15\left(B_{1}\right)$ and $30\left(B_{2}\right)$ days.

I $\sim$ IV : Levels of reduction rates of D. I., i. e., I : not changed $(0-25 \%)$, II : slightly reduced $(26-50 \%)$, III : moderately reduced $(51-75 \%)$, and IV : greatly reduced $(76-100 \%)$.

*: number of subjects. ** : cumulative number of subjects.

Table 5 The cumulative analysis of variance of D. I..

\begin{tabular}{c|r|r|r|l}
\hline Factors & \multicolumn{1}{|c|}{ s. s. } & d. f. & V & Fo. \\
\hline Dentifrices & 17.2101 & 3 & 5.7367 & $5.857^{* *}$ \\
Periods & 2.1812 & 3 & 0.7270 & 0.742 \\
$\mathrm{~A} \times \mathrm{B}$ & 0.9911 & 3 & 0.3303 & \\
$\mathrm{e}$ & 351.6175 & 360 & 0.9767 & \\
$\mathrm{e}^{\prime}$ & 352.6086 & 363 & 0.9794 & \\
\hline Total & 371.9999 & 369 & &
\end{tabular}

** $: \mathrm{P}<0.01$
のに対し，対照群のそれは $12.9 \%$ であ，明らかな差が 認められている。但し，「有效例」での比較では実呀群 $22.6 \%$ 対し, 対照群は $48.4 \%$ であることから, 実唒群 の「有效例」が「著效例」に移行している倾向であった。 また，実跧群の「不変例」は対哭群に対し，「やや有效 例」に移行しているようであった。

1 力月後の効果をみてみると, 実験样の「著效例」と 刘區样の「不変例」が入れ替ったような傾向を示してお り，それ故㹢果の差が1ランクずれてあらわれていた。

\section{2) C.I. 倾の摡繁成嚗}

(1) C.I. 优の檢形回数による変秒

C.I. 佶の钼察結果については，D.I. 做による微察と 


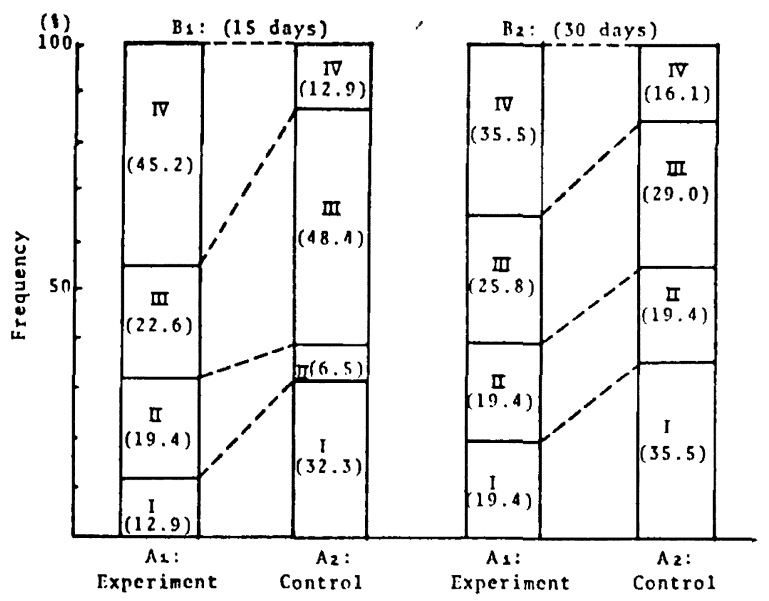

Fig. 8 An estimation graph of factor $A \times B$ of D.I. $(P<0.01)$.

$A$ : Test groups, i. e., Experimental $\left(A_{1}\right)$ and Control $\left(A_{2}\right)$ groups.

B : Experimental periods, i. e., $15\left(B_{1}\right)$ and $30\left(B_{2}\right)$ days.

I $\sim$ IV : Frequency of subjects grouped by the reduction rates of D.I. i. e., I : not changed (0-25\%), II : slightly reduced (26-50\%), III : moderately reduced $(51-75 \%)$, and IV : extremely reduced $(76-100$ $\%)$.

Table 6 The daily changes of C. I..

\begin{tabular}{|c|c|c|c|c|c|c|c|}
\hline \multirow{2}{*}{\multicolumn{2}{|c|}{$\underbrace{\text { Test groups }}_{\text {Dentition }}$}} & \multicolumn{3}{|c|}{ Experimental group $(n=31)$} & \multicolumn{3}{|c|}{ Control group $(n=31)$} \\
\hline & & Start & 15 days & 30 days & Start & 15 days & 30 days \\
\hline \multirow{3}{*}{ Maxilla } & Buccal & $0.092^{*}$ & $\begin{array}{l}0.019 \\
(79.3)^{* *}\end{array}$ & $\begin{array}{c}0.005 \\
(94.6)\end{array}$ & 0.086 & $\begin{array}{c}0.011 \\
(87.2)\end{array}$ & $\begin{array}{c}0.011 \\
(87.2)\end{array}$ \\
\hline & Lingual & 0.097 & $\begin{array}{c}0.006 \\
(94.8)\end{array}$ & $\begin{array}{c}0.005 \\
(94.8)\end{array}$ & 0.108 & $\begin{array}{c}0.018 \\
(83.8)\end{array}$ & $\begin{array}{c}0.011 \\
(89.8)\end{array}$ \\
\hline & Total & 0.189 & $\begin{array}{c}0.025 \\
(86.8)\end{array}$ & $\begin{array}{c}0.010 \\
(94.7)\end{array}$ & 0.194 & $\begin{array}{c}0.029 \\
(85.1)\end{array}$ & $\begin{array}{c}0.022 \\
(88.7)\end{array}$ \\
\hline \multirow{3}{*}{ Mandibula } & Buccal & 0.064 & $\begin{array}{c}0.008 \\
(87.5)\end{array}$ & $\begin{array}{c}0.005 \\
(92.2)\end{array}$ & 0.086 & $\begin{array}{c}0.014 \\
(83.7)\end{array}$ & $\begin{array}{c}0.000 \\
(100.0)\end{array}$ \\
\hline & Lingual & 0.312 & $\begin{array}{c}0.134 \\
(57.1)\end{array}$ & $\begin{array}{c}0.118 \\
(62.2)\end{array}$ & 0.301 & $\begin{array}{c}0.153 \\
(49.2)\end{array}$ & $\begin{array}{c}0.124 \\
(58.8)\end{array}$ \\
\hline & Total & 0.376 & $\begin{array}{c}0.142 \\
(62.2)\end{array}$ & $\begin{array}{c}0.123 \\
(67.3)\end{array}$ & 0.387 & $\begin{array}{c}0.167 \\
(56.8)\end{array}$ & $\begin{array}{c}0.124 \\
(68.0)\end{array}$ \\
\hline \multicolumn{2}{|c|}{ Total } & 0.565 & $\begin{array}{c}0.167 \\
(70.4)\end{array}$ & $\begin{array}{c}0.133 \\
(76.5)\end{array}$ & 0.581 & $\begin{array}{c}0.196 \\
(66.3)\end{array}$ & $\begin{array}{c}0.146 \\
(74.9)\end{array}$ \\
\hline
\end{tabular}

* : mean C.I. per tooth surface. **: The reduction rate (\%) from the C.I. at start.

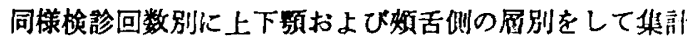
した結果は Table 6 に示した通りである。まず初回佔の 傾向は, D.I. 做の場合と同椓に下强の舌側が最も夜い状 摼を示し，すなわち，実倹群に振り分けられたものが 0.312であり，対照样のそれは0.301であった。しかしな がら，最も少なかったのは，前述の D.I. 值では上預の
口蓋倒であったのが C.I. 值では下影の煩侧にみられた。 初回 C.I. 值圭最初の值とした場合の経日による城少 宗の推移は，再棑间でつぎのように示された。まず，实

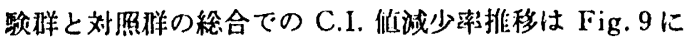
示すとおり，実駼群の半月後では70.4\%，1 1 力後では $76.5 \%$ でったのに対し，対照群のそれは，それぞれ 


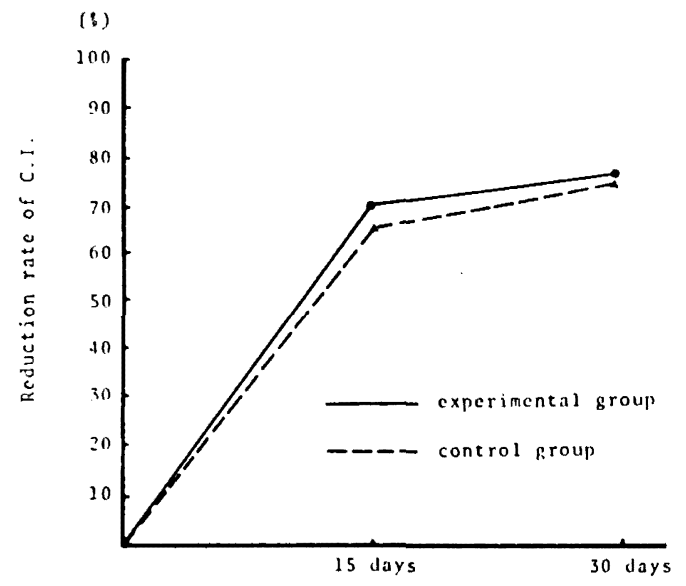

Fig. 9 Daily changes in reduction rates of C.I. (full mouth).

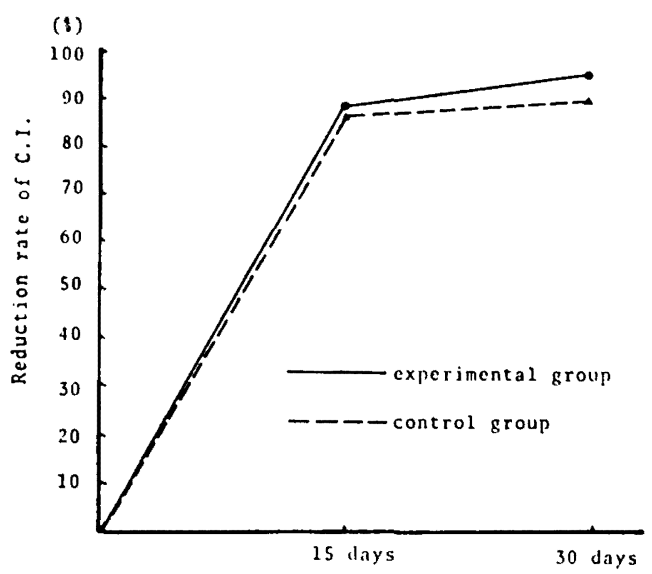

Fig. 10 Daily changes in reduction rate of C.I. on the maxilla.

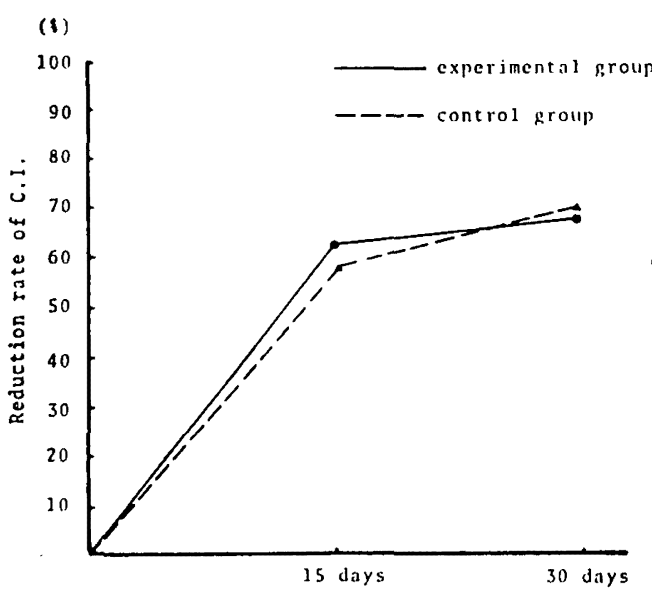

Fig. 11 Daily changes in reduction rates of C.I. on the mandibula.
66.3\%，74.9\%であった。それ故，实讶群は対照群に対 し，実数では若下高い傾向にあるが，いずれも70\%前後 の娍少効果であり大きな差はみられなかった。

つぎに、これらの娍少隼を，前述の D.I. 值による镜 繁と同栚，上下頕に分けて示したのが Fig.10および Fig. 11である。その結果は両群ともほとんど同程度の值を示 しており，差はあらわれていない。但し上下顥間の減少奻 果を比较してみると，前述の歯垢について，下影 (57.2 $\%)>$ 上類 (42.0\%) であったのに刘し，得石において は企く逆で，上顥 $(88.8 \%)>$ 下影 $(63.6 \%)$ で示された。

一方，その内容をさらに分析する望味から，上積およ び下頼のそれぞれについて，煩舌間に分けて両洋閒の差 をみたのが Fig.12, 13,14および Fig.15である。その結

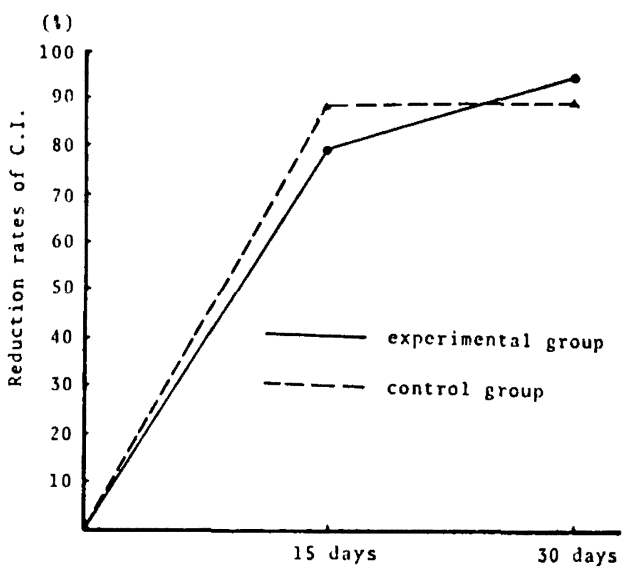

Fig. 12 Daily changes in reduction rates of C.I. on the maxilla and buccal tooth surface.

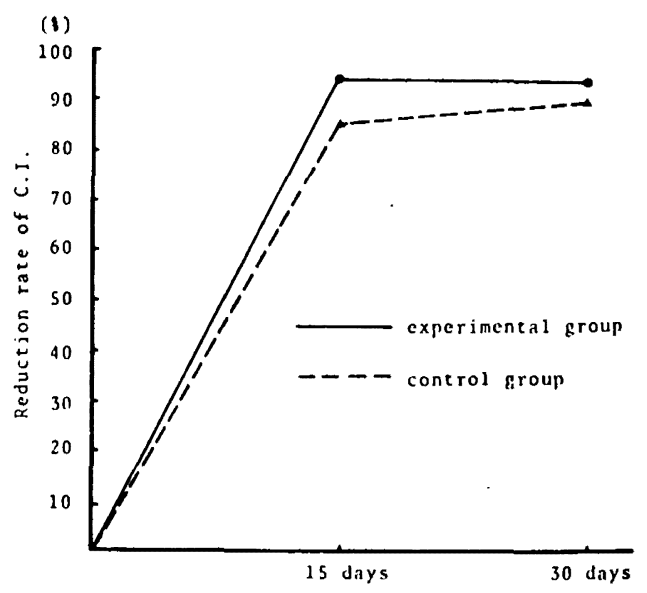

Fig. 13 Daily changes in reduction rates of C.I. on the maxilla and lingual tooth surface. 


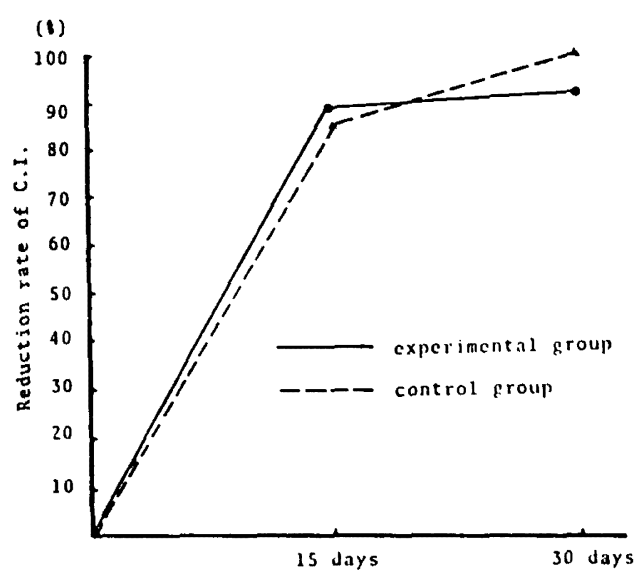

Fig. 14 Daily changes in reduction rates of C.I. on the mandibula and buccal tooth surface.

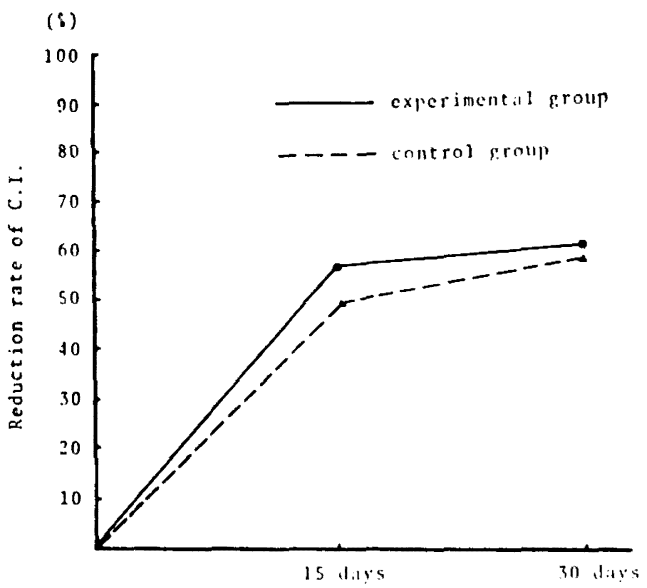

Fig. 15 Daily changes in reduction rates of C.I. on the mandibula and lingual tooth surface.

Table 7 The effect of test dentifrices on the reduction rate of C.I..

\begin{tabular}{|c|c|c|c|c|c|c|}
\hline \multicolumn{2}{|c|}{ Factors $\begin{array}{c}\text { Levels of } \\
\text { reduction } \\
\text { rates }\end{array}$} & \multirow{2}{*}{$\begin{array}{c}I \\
(\sim 25 \%) \\
4^{*}\end{array}$} & \multirow{2}{*}{$\begin{array}{c}\text { II } \\
\frac{(26 \sim 50 \%)}{2(6)^{* *}}\end{array}$} & \multirow{2}{*}{$\begin{array}{c}\text { III. } \\
\frac{(51 \sim 75 \%)}{15(21)}\end{array}$} & \multirow{2}{*}{$\begin{array}{c}\text { IV. } \\
\frac{(76 \% \sim)}{10(31)}\end{array}$} & \multirow{2}{*}{ Total } \\
\hline & $\mathrm{B}_{1}$ (15 days) & & & & & \\
\hline Experimental & $\mathrm{B}_{2}$ (30 days) & 3 & $1(4)$ & $14(18)$ & $13(31)$ & 31 \\
\hline \multirow{2}{*}{$\underset{\text { Control }}{\mathbf{A}_{2}}$} & $\mathrm{~B}_{1}$ (15 days) & 7 & $2(9)$ & $13(22)$ & $9(31)$ & 31 \\
\hline & $\mathrm{B}_{2}$ (30 days) & 6 & $0(6)$ & $11(17)$ & $14(31)$ & 31 \\
\hline \multicolumn{2}{|c|}{ Total } & 20 & $5(25)$ & $53(78)$ & $46(124)$ & 124 \\
\hline
\end{tabular}

A : Test groups, i. e., Experimental $\left(A_{1}\right)$ and Control $\left(A_{2}\right)$ groups.

$B$ : Experimental periods, i. e., $15\left(B_{1}\right)$ and $30\left(B_{2}\right)$ days.

I $\sim$ IV : Levels of reduction rates of C. I., i. e., I : not changed $(0-25 \%)$, II : slightly reduced $(26-50 \%)$, III : moderately reduced $(51-75 \%)$ and IV : greatly reduced $(76-100 \%)$.

$*$ : number of subjects. $\quad * *$ : cumulative number of subjects.

果は, 煩舌に分けて内容をみても, 両群䦥の明らかな差 はあらわれていない。

以上の栋から，C.I. 值についてはどの部位からみて も両群問の差, すなわち, dextranase 添加による效果 は、汪とんど認められなかった

(2) C.I. 值の統計的钼综

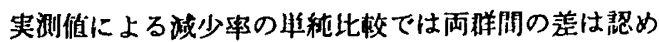
られなかった。しかし確諗のため D.I. 佰による場合と 同様に統計処理をするため集計した結果は Table 7 に示 すと扔りである。またこれらを解析した結果は，Table 8 の分散分析表に示寸とおりで予期した通りA因子の雨 群間には全く有意の差が検出されなかった。同様にB因 子の期間についても有意の差は認められず, D.I. 值の壯
Table 8 The cumulative analysis of variance of C. I..

\begin{tabular}{c|r|r|r|r}
\hline Factors & \multicolumn{1}{|c|}{ s.s. } & d.f. & \multicolumn{1}{c|}{ V } & Fo. \\
\hline Dentifrices & 3.3986 & 3 & 1.1328 & 1.127 \\
Periods & 3.7028 & 3 & 1.2342 & 0.814 \\
A $\times$ B & 0.1883 & 3 & 0.0627 & \\
e & 364.7102 & 360 & 1.0130 & \\
$\mathrm{e}^{\prime}$ & 364.8985 & 363 & 1.0052 & \\
\hline Total & 371.9999 & 369 & &
\end{tabular}

と同様に半月以降は㮐ばいであることが䂾恕された。

次にA因子の两群開の差について，その内容をみるた め推定グラフで示したのが Fig.16である。その絬果例え 


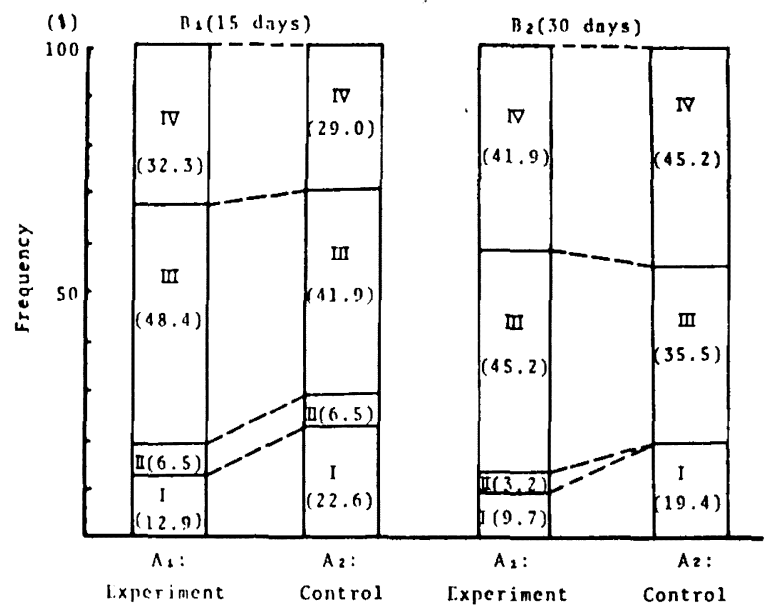

Fig. 16 An estimation graph of factoa $A \times B$ of C.I. (N.S.)

$A$ : Test groups, i. e., Experimental $\left(A_{1}\right)$ and Control $\left(A_{2}\right)$ groups.

$B$ : Experimental periods, i. e., $15\left(B_{1}\right)$ and $30\left(B_{2}\right)$ days.

I $\sim$ IV : Frequency of subjects grouped by the reduction rates of C.I., i. e.,

I : not changed $(0-25 \%)$, II : slightly reduced $(26-50 \%)$, III : moderately reduced $(51-75 \%)$, and IV : extremely reduced $(76-100$ $\%)$.

ば，C.I. 低 1 力月後では実駼样の「不変例」9.7\%に対 し，刘照棎のそ机は $19.4 \%$ で，若下の效果は認められつ

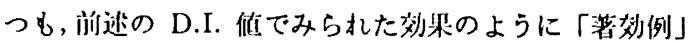
では差はあらわれていなかった。

\section{考察}

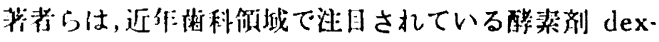

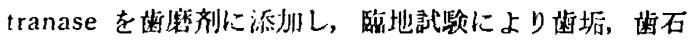
の除去效果について梌郡を行なったが， dextranase の 源加团を20001位に没定したのは，次のような理由から である。阢ち、落者らのうち 1 人が行なった先の头㤉25,26) で, dextranase 2000川位添杊の条俳が效果を榆出する

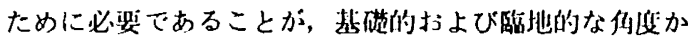

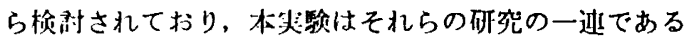

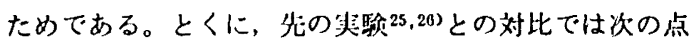
が相邈している。その1 つは先の契駼における砳究対象

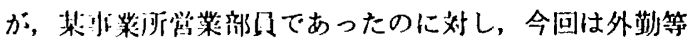

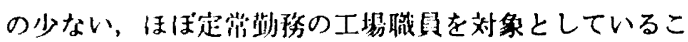

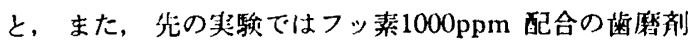
を其本べースとして，こ扎に dextranase 添杊の有無で

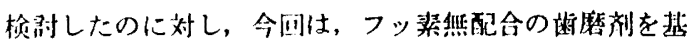

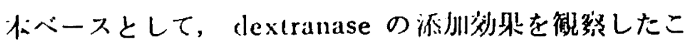
とが大きな站翼である。しかし本紕は， dextranase 添

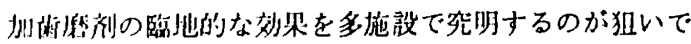

あった。

つぎに，实験条件，特に刷掃方法については，今回特別 な指定を行なわず現在各被梌者が契施している方法に一 任した。本来この䄬の研究では, 蝴志 ${ }^{30}$ が行なったよう な個人閌のバラッキを少なくナるため，ローリング法な どに統一して果施することが通常である。しかしなが ら，茷者らはむしろ個人閌のバラッキが存在した上での

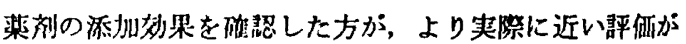
得られるのではないかと考えている。さらに，今回のよ 5に30〜 50代の被梌者に则捅指迸を全員に平均して習熟 させるのは困難と判断し，特に短期問での指荋では，む しろ実験のためのバラッキを加えてしまうのではないか と推察したので，刷墇法については指示をしなかった。

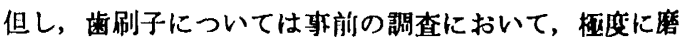
耗したものを使用している例がみられたので，同一品を 提供し統一化をはかった。

対象となった被検者の初部㭙の微察では, 菌垢付着の 状侹が最も高い方から，下影・舌侧 $(0.229)>$ 上影・頼 侧 $(0.140)>$ 下影 - 煩侧 $(0.099)>$ 上影 - 口蓝借 $(0.044)$

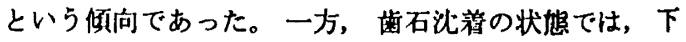

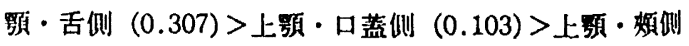
(0.089) >下影・煩纵 (0.075) とい5修向であり，いず れも下顠の舌侧が最も低い部位に対し 4 5 倍の高い状 隹にあった。これらの結果については, 新非:31の報告と 
相反している。すなわち，新非の成結では口腔泎挪を 1

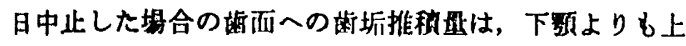
腬に多く，舌口蓝侧よりも唇始似に多かったという。ま た Wade ${ }^{82}$, Löe $5^{33)}$ も類似の成績を報告しているこ とから，今後この百での微底的な究明が必要と思われ る。著者らの今回の実駼において，これら初钐㭙の部位

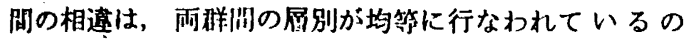

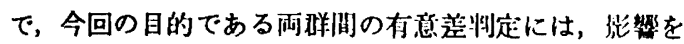
与えていないと考えている。

D.I. 值についてみると今国の成絖では 实駼样は，半 月後に $66.9 \%, 1$ 力月後には $62.3 \%$ の娍少教果であった。 一方相当する対照群は，そ机ぞれ $43.3 \% ， 34.4 \%$ であっ たことから，統計的検定を待たずに明らかな差が認めら れている。これらは著者らの先の実駰20)で芈月経過後 に, dextranase 添加の実呀样が $74.7 \%$ ，また対照群の それが41.5\%であったことと対比するとほほ近似した䋧 果が得られ，被検対象者などが買なっても dextranase の添加による㹝果は,十分に立証し得たものと推察した。 つぎに経日的な而では，半月経過後に対し1力月後で は诚少㹝果に若干の戻りがみられていた。これらは半月 後でほほ効果の限界に達したものと推定できる。特に歯 垢については数日間という短期間での生成が可能である ことから，減少した状態での生成，除去が綝り返されて いたものと思われる。しかし画石についてはその生成が 長期間を要することから，半月後に対し1カ月後では若 干娍少勃果が增加倾向にあったと考えられる。

本研究において，実雅群の堿少效果と同栚に，刘照倠 の诚少效果もかなり大きく認められている。この傾向は 岩井 ${ }^{34}$ ，沢田 ${ }^{35)}$ が報告しているようにこの桖の研究で

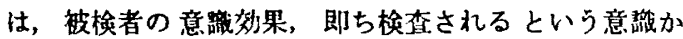
ら，従来より丹念に磨くという現象が例いたためと判断 される。從って，あくまでも両羘荫の羑が dextranase 添加による効果と判断され得ることができる。

C.I. 值の成績については，実邪样の場合半月経過後 で70.4\%，1 力月後では76.5\%の減少奻果がみられたの に対し，対照群のそれは $66.3 \%$ および $74.9 \%$ であり，両 群間の差はほとんど認められていない。尚，これらにつ いては，上下影に分けて視察しても，また煩舌に分けて 篗察しても全く同栐な曲線を描いており，差は検出され なかった。このことは， dextranase の效果を推察する

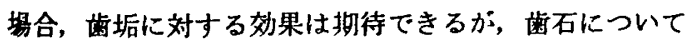
は效果が十分に及ばないことを示唆しているものと思わ れる。事実, dextranase の效果を車つける基䃈的成 䋘13-15)が，齿垢生成過程でのデキストラン形成阻止作用
あるいは分解作用という点からみても，掬石除去までに 及ばないことは当然の結策と判断される。

D.I. 佔，C.I. 值の結果について部位別に分け，いわ

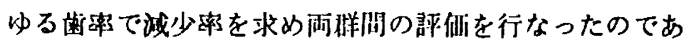
るが，統那船析上は被检者各々について減少事を水め， それら各被検者がどの泪效猚に属したかという者率でと

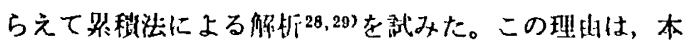

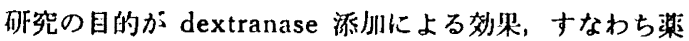
効㭘定であること，さらに dextranase がどの菲协样で 效果を発挪したかを㙀问したかったからである。その結

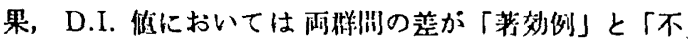
変例」が入れ替ったような形で発报していることなどが 検出され， dextranase の歯垢に対する覧地的な效果か 分析的な究吸できたと考えら北た。

\section{結論}

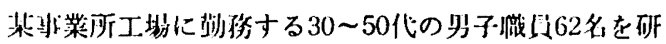
究対象として，1 $\mathrm{g}$ 当り dextranase 2000!位添刜した

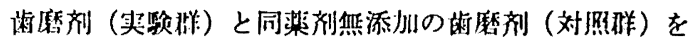
臨地的に比校㭘剖した。その結果は次のと㧍りである。

1) Debris Index (D.I,) について

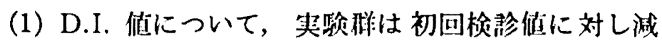
少㳯は半月経過後には $66.9 \%$ 減少し，1 力月経過後には 若干戻りがみられたが $62.3 \%$ の堿少が羿められた。しか し刘照群のそ机は弱く，それぞれ43.3\%，34.4\%にとど まった。

（2）とくにこれら雨群間の差は，㛲侧において刘梁の 蕫を引き出していた。

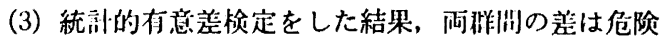
率 $1 \%$ で検出され，実験排では，被検者中 $35.5 \%$ の人が $75 \%$ 以上の減少效果（著刘例）を示したのに対し，刘照 群のそれは低く $16.1 \%$ であった。

2) Calculus Index (C.I.) について

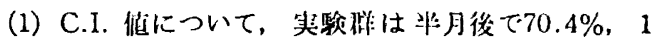
力月後で76.5\%の城少案であったのに対し，刘照砩はそ れぞれ $66.3 \% ， 74.9 \%$ であり，奏数では実駼碚は若下夜 、傾向にあった。しかしながら，統計的には杕意の善は 羿められなかった。

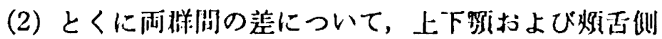
に分けて钼察したが，いずれの部位からみても有狛な差 はみいだせなかった。

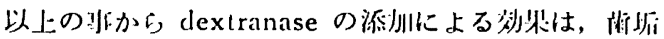
に対する作用は猢待し得るが，菌不については，その排 街はうすいと判断された。 


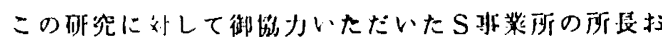

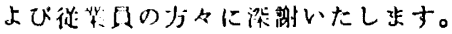

\section{文献}

1) Suomi J. D. and Doyle, J.: Oral hygiene and periodontal disease in a adult population in the United States: J. Periodont., $43: 677,1972$.

2) Sax, S. R., Green, J. C., Bohannan, H. M. and Vermillion, J. R. : Oral dedris, calculus and periodontal disease in beagle dog: Periodontics, $5: 217,1968$.

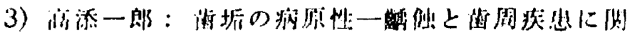

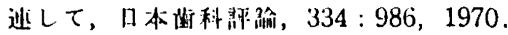

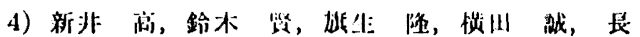

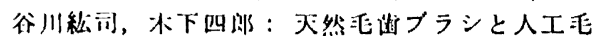

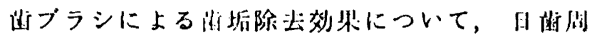
滺, 19(2) : 170, 1977.

5）决下四郎，新井京：プラークコントロールに

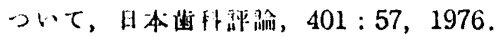

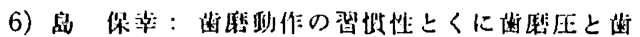

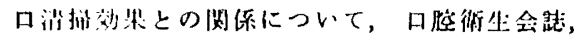
$17(3): 11,1967$.

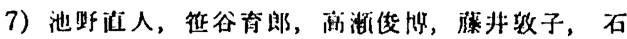
川純：ブラッシング指澊に扰けるモチベーショ

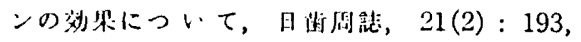
1979.

8) Matisyohu, W: : Behavioral Motivation : J. Periodont, 44:489, 1973.

9) Hausman, E.: Motivation-Keyto patient success in mechanical plaque control: J.A. D.A. $92: 403,1976$.

10）大西正男，北村中也，村上淑子：外来除石想者 の特性とそのモチベーション，口腔術生会䩞， 20(4) : 39, 1971.

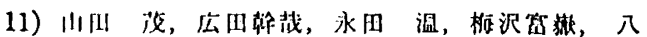
整然子：Chlorhexidine 店丹に上る诲垢坐成抑

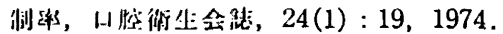

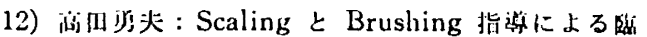

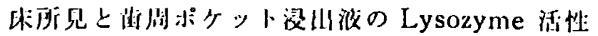

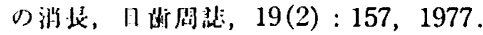

13) Bowen, W. H.: Effects of dextranase on cariogenic and non-cariogenic dextrans; Brit. Dent. J., 124 : 347, 1968.

14) Walker, G. J. and Pulkownik, A. : Degradation of dextran by an $\alpha-1,6 \cdot$ glucan glucanohydrolase from Streptococcus mitis; Carbohydr. Res., $29: 1,1973$.

15) Hoffman, S., Tow, H. D. and Cole, J. S. : Scanning electron microscope studies of dextranase treated plaque streptococci; J. Dent. Res., $52: 551,1973$.

16) Fitzgerald, R. J., Spinell, D. M. and Stout, T. H. : Enzymatic removel of artificial pla- ques; Arch. Oral Biol., $13: 125,1968$.

17) Konig, K. G. and Guggenheim, B. : In-vivo effects of dextranase on plaque and caries; Helv. Odont. Acta, 12 : 48, 1968.

18) Fitzgerald, R. J., Keyes, P. H., Staut, T. H. and spinell, D. M. : The effects of a dextranase preparation on plaque and caries in hamsters. A preliminaty report; J.A.D.A., $76: 301,1968$.

19) Block, P. I., Dooley, C. L. and Howe, E. E. : The retardation of spontanaous periodontal disease and the prevention of caries in hamsters with dextranase; J. Periodont., $40: 105,1969$.

20) Guggenheim, B., König, K. G., Mühleman, H. R. and Regolrati, B.: Effect of dextranase on caries in rats horbouring on indigenous cariogenic bacterial flora; Arch. Oral Biol., 14 : 555, 1969.

21）大西正男，尾崳女子，挆村窝传子：テキストラ

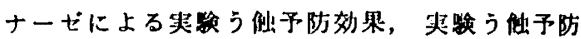
の政栄(11)，口腔術生会鼔, 20(4)：40，1971.

22) Keyes, P. H., Hicks, M. A., Goldman, B. M., McCabe, R. M. and Fitzgerald, R. J. : Dispersion of dextraneous bacterial plaques on human teeth with dextranase; J.A.D.A., $82: 136,1971$.

23) Lobene, R. R. : A clinical study of the effect of dextranase on human dental plaque; J.A.D.A., $82: 132,1971$.

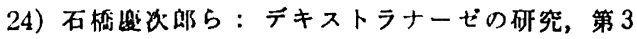

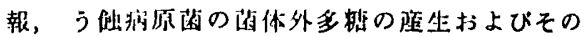
多格の Chaetomium gracile テキストラナーゼ に上る分解，末㜓。

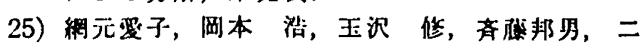
上非之: Chaetomium gracile 由米の Dextranase による in vitroの循垢浴解刘果ならびに

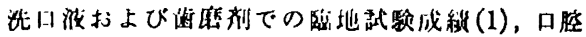
衙尘会乱， $28: 185,1978$.

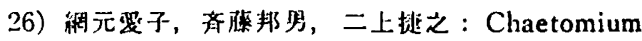

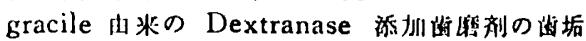

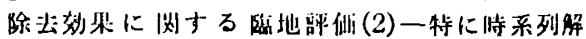
析による考䋈について一，口腔衙尘会范，28： 276, 1978.

27) Green, J. C., Vermillion, J. R. : The oral hygiene index, A method for classifying oral hygiene status, J.A.D.A., $61: 172,1960$.

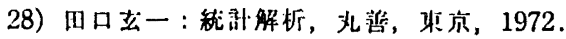

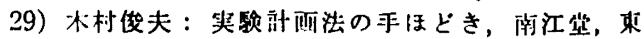
京, 1969.

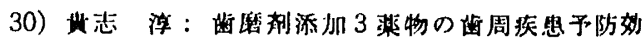

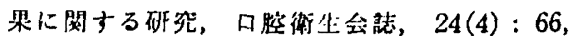
1974 .

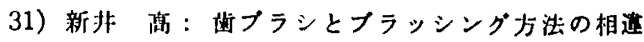

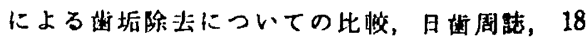


(1) : 13, 1975 .

32) A. B. Wade : Brushing practices of a group with periodontal disease; The prevention of periodontal disease. Edited by John E. Eastone, et al: London, 1972 : Henry Kinpton : 218.

33) Löe, H. Theilade, E., Jensen, S. B. : Expe- rimental gingivitis in man, J. Periodont., $36: 177,1965$.

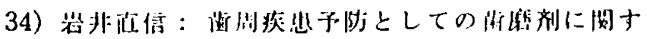

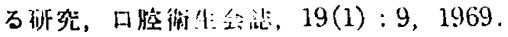

35）沢田洋三：感光色れ NK 355添加クリーム捄上

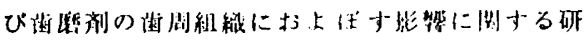

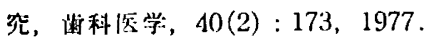

Abstract: The clinical effect on plaque control of dentifrice containing dextranase, Tyūya KITAMURA*, Saki MORIGUCHI*, Emiko TERADA*, Kunio SAITO**, Katsuyuki FUTAKAMI**. In general, dextranase is an effective plaque control agent which enzymatically resolves and removes dental plaque.

In this study, the effect on plaque control of dextranase prepared from chaetomium gracile and added to a dentifrice was examined in clinical tests.

Sixty-two male subjects aged about thirty to fifty and employed in a factory, were divided into two groups. Each group used a test dentifrice containing 2000 units of dextranase per gram and a placebo dentifrice without dextranase for one month. Then the OHI was evaluated.

Regarding the debris-index, reduction rates of the test and the placebo dentifrice groups were 62,3 and $34,4 \%$, respectively, and a statistically significant difference $(P<0,01)$ was observed between them.

On the other hand, in the calculus-index, reduction rates of the test and the placebo dentifrice groups were 76,5 and $74,9 \%$ respectively. Their effects were almost the same and there was no statistically significant difference.

These results suggested that an effect on plaque control of dextranase could be expected in clinical use, but that it would have on effect on the reduction of calculus. 